10.2478/arhss-2018-0003 Applied Research in Health and Social Sciences, Vol. 15, No. 1, 2018

\title{
CONCEPTUALISATION OF SELF-EDUCATION FOR HEALTHY LIFE STYLE: FROM SATISFACTION OF PSYCHOLOGICAL NEEDS TO IMPLEMENTATION OF LIFE OBJECTIVES
}

\section{VAIVADA Saulius}

Šiauliai University, Department of Social Welfare Studies and Physical Culture, Šiauliai, Lithuania

\section{ŽYDŽIŪNAITĖ Vilma}

Vytautas Magnus University, Academy of Education, Kaunas, Lithuania

\begin{abstract}
The descriptive conceptual analysis-based article aims to substantiate the construct of person's self-education for healthy life. So why the research question in the following: How is conceptualised the person's selfdevelopment for a healthy lifestyle in the Self-Determination Theory on the basis of the natural psychological needs of the person, motivated and pursued by the theory?

Personal self-education in the education science is associated with a modern, dynamic and holistic educational concept, which implies a life-long process of human development and an individual path. By planning, organizing, managing and controlling the process of personal development, a person takes responsibility for the direction, goals, ways and final result of self-education. A healthy lifestyle as a kind of self-education fulfills the conditions of holistic development and contains physical, mental, social, spiritual self-education. In conceptualizing a person's self-education for a healthy lifestyle, it is best to refer to the intrapersonal health education theories. These theories emphasize the influence of environmental and social factors on a person's lifestyle, and the person's knowledge, skills, motivation, attitudes and free determination to change oneself and his/her lifestyle.

The Self-Determination Theory reveals the trends of personal development and calls it eudaimony or a path of life based on the satisfaction of general personal psychological needs - autonomy, competence and conenction, as well as the pursuit of inner goals and universally recognized values. Realized and satisfied natural psychological needs encourage person's inner energy, internal motivation associated with person's native inclination for development. In pursuit of personal development and health-oriented goals, a person finds a sense of meaning in his or her activity and experiences a state of well-being.
\end{abstract}

Keywords: Eudaimony; Healthy life style; Individual self-education; Natural psychlogical needs; Selfdetermination theory. 
10.2478/arhss-2018-0003 Applied Research in Health and Social Sciences, Vol. 15, No. 1, 2018

\section{Background}

Personal self-education in the education science is associated with a modern, dynamic and holistic educational concept, which implies a life-long process of human development and an individual path, in which awareness, responsibility, systematic activity and purposefulness are important (Arnold, 2010; Carlsburg \& Wehr, 2010). By planning, organizing, managing and controlling the process of personal development, a person takes responsibility for the direction, goals, ways and final result of self-education. In other words, self-education is defined as an active process in which a person who develops is an entity rather than an object of events.

A healthy lifestyle as a kind of self-education fulfills the conditions of holistic development as it contains physical, mental, social, spiritual self-education associated with the appropriate levels of personal health (Wiggins, 2011; Salci et al., 2013). Healthy lifestyle determines a person's behavior and quality of life, and is related to health - a process that involves enthusiasm to live and a lifestyle that has been created for allowing to experience the fullness of life (Jankauskas, 2015). A healthy lifestyle, like any other person's choice makes sense for daily life activities and for the deliberate refusal of more common forms of behavior and consumption (Giddens, 2000). Precisely through free individual choices that the individual's individuality manifests itself, and the process of personality self-evaluation takes place.

In conceptualizing a person's self-education for a healthy lifestyle, it is best to refer to the intrapersonal health education theories and the models based on them. These theories emphasize not only the influence of environmental and social factors on a person's lifestyle, but also the person's knowledge, skills, motivation, attitudes and free determination to change oneself and his/her lifestyle. Most of the intrapersonal health education theories have the same general educational goal: a positive change in the person's behavior with regard to a healthy lifestyle. However, the behavioral change and the healthy lifestyle process are interpreted differently.

Theory of Chaos, which is substantiated by the mathematical modeling is based on the approach that small changes in personal knowledge, attitude or performance can dramatically change motivation and behavioral outcomes. Therefore, a person's behavioral changes in regard to health are: 1) a quantum event; 2) similar to a chaotic process, which is very changeable and depends on the initial conditions, making it difficult to predict; 3) complex systems that integrate multiple components and which interact in an indirect manner; 4) systems with results that are often higher than the sum of their individual parts (Resnicow \& Vaughan, 2006; Resnicow \& Page, 2008; Bussolari \& Goodell, 2009). According to the theory presented, a person's healthy lifestyle should be treated as changeable, hardly predictable, more chaotic than a planned, systematic process of personal development. 
10.2478/arhss-2018-0003 Applied Research in Health and Social Sciences, Vol. 15, No. 1, 2018

All other intrapersonal health education theories define the change of person's behavior (and thus the process of self-education) as a deterministic, linear process. One of these theory, Behavioral Change Stage Theory, often referred to as The Theory of Transtheoretical Model, interprets the personal behavioral changes in the context of a process that includes individual steps (Prochaska \& DiClemente, 1983; Prochaska, 2008). Theory of Health Belief Model substantiates the healthy lifestyle process through the key drivers of behavioral change (Janz \& Becker, 1984; Čepanauskienè \& Kalibatienè, 2010; Juozapavičienė \& Riklikienė, 2013): 1) perceived vulnerability; 2) perceived seriousness; 3) perceived benefits; 4) perceived obstacles; 5) health motivation; 6) trust. Theory of Salutogenesis seems to be somewhat different in this context, where a person is treated as a whole and focuses on health determinants rather than risk factors (Antonovsky, 1987). The core category of Salutogenesis Theory - personal internal coherence, as innternal orientation, is expressed by positive personal relationships with the world and him/herself (Antonovsky, 1987; Reinshagen, 2008). Therefore, the process of personal self-education in this theory should be analyzed on the basis of the development of internal personal coherence and its main dimensions of (self)development.

The Self-Determination Theory is selected for conceptualization of the subject of the research - a person's healthy lifestyle. In it, personal development trends are based on basic psychological needs that determine internal motivation - autonomy, competency and connection (Ryan, 1995; Deci, Ryan, 2000; Ryan \& Deci, 2000 a, b; Deci \& Vansteenkiste, 2004; Vansteenkiste \& Ryan, 2013), a person's behavior oriented towards internal goals and values (Deci \& Ryan, 2000; Deci, Vansteenkiste, 2004; Vansteenkiste et al., 2006; Vansteenkiste et al., 2010) and the pursuit of eudaimony (Ryan et al., 2008a). The applicability of the chosen theory to the research object is justified by the following aspects: a spectrum of research spacec, which is based on Self-determination Theory, covering both health-related and education science-related research issues (Ryan, 2009); refining the cornerstones of theory based on different subtheories - Cognitive Evaluation Theory, Organismic Integration Theory, Causality Orientations Theory, Basic Needs Theory and Goal Contents Theory (Haggera, Chatzisarantisb, 2008; Wilson et al., 2008; Ryan, 2009; Vansteenkiste et al., 2010) and the orientation of the mentioned theory to the manifestation of personality self-education and the chosen healthy lifestyle in terms of fullness, happiness or well-being (in Greek language - eudaimonia) sąvokomis (Ryan et al., 2008a).

The research issue can be narrowed through the following research question: How is conceptualised the person's self-development for a healthy lifestyle in the Self-Determination Theory on the basis of the natural psychological needs of the person, motivated and pursued by the theory?

Research aim is to substantiate the construct of person's self-education for healthy life. 


\section{A healthy lifestyle and psychological needs that determine a person's motivation}

Personal development, integrity, good mental and physical health, and health-friendly behavior are shaped by the satisfaction of three natural psychological needs - autonomy, competence and communication, according to authors of the Self-determination Theory (Ryan, 1995; Deci \& Ryan, 2000; Ryan \& Deci, 2000 a, b; Ryan et al., 2008b; Vansteenkiste \& Ryan, 2013). Self-regulation, personal choices, the ability to fully assess specific (self)educational opportunities and match them with personal needs and feelings are factors, which make sense for the personal autonomy within the process of self-education (Ryan \& Deci, 2006). With a psychological need for competence, a person expresses a desire to be active in cooperation with others and to experience satisfaction with his or her efforts to manage personal life (Deci \& Vansteenkiste, 2004). The need for communication is realized by the person in communicating with others and caring for others (Deci \& Vansteenkiste, 2004) and maintaining a meaningful relationships (connections) with them (Reis et al., 2000). In the perspective of long-term health-oriented behavioral change and psychological well-being, basic psychological needs are associated with the person's experience of (Teixeira et al., 2011):

- competence is manifested as formed skills, self-efficacy, and positive tests;

- autonomy manifests itself as acceptance, will, perceived choice and management;

- the relationship (connection) is manifested as unconditional acceptance, sincerity, and association.

Balanced satisfaction of all three mentioned above natural needs is essential for personal harmony and personal well-being (Sheldon \& Niemiec, 2006).

The internal motvation is the basic of self-education for healthy lifestyle, as well as for any person's development (Deci \& Vansteenkiste, 2004). Autonomous self motivation for self-determination and a healthy lifestyle is determined by the person's proactivity, innate tendency to development, pursuit of knowledge, satisfaction of basic psychological needs, and regulatory processes such as interest, joy, and internal satisfaction (Ryan \& Deci, 2000). However, if the person has the limited availability to use this resource, thus the external reinforcement is needed to integrate external regulation and internalisation of activity in the (self)education process. Therefore, both internal and external motivation are important in the process of self-education for a healthy lifestyle, which is associated with four different stages of regulation in the Self-determinaton Theory (Ryan \& Deci, 2000):

1) external regulation (in this case, personal actions are directed towards the awarding of prizes or the avoidance of penalties);

2) introjection (partly controlled form of motivation to avoid guilt or anxiety, pride, and ego satisfaction); 
10.2478/arhss-2018-0003 Applied Research in Health and Social Sciences, Vol. 15, No. 1, 2018

3) identification (the form of motivation, which reflects a conscious understanding of the purpose of the activity);

4) integration (when the identified regulation is fully assimilated to the personality's 'I' component). However, the above-mentioned works draw attention to the fact that external motivation is effective when initiating a person's behavioral change, but external resources are not enough to preserve new behavioral patterns for a long time (Segar, 2015).

Motivation for a healthy lifestyle is determined by the satisfaction of all three of mentioned (above) natural psychological needs. In the works that are assigned to the Self-determination Theory, there is evidence of internal motivation in relation to all basic needs, but it is nevertheless recognized that the basis for internal motivation is the need to feel competent and autonomous (Deci \& Vansteenkiste, 2004). The impact of external motivation is also enhanced by satisfying all three needs, but internalization and self-regulation are mostly driven by the need for connection (Ryan \& Deci, 2000 b). Through personal change and by becoming more conscious, a person begins to behave prosocially, thus favoring not only him/herself but also others (Ryan et al., 2008 a).

\section{Self-education for healthy lifestyle and goals of personal activity and life}

Particular individual self-education activities for healthy lifestyle are related to the health preservation and health promotion, well-being and personal development and rising the consciousness. Therefore, a person's health in the context of self-education is identified as a reflection of a person's experience and performance that gives meaning and satisfaction to his or her life (Segar, 2015). Authors of Selfdetermination Theory consider that all goals of personal activity, depending on the object of their pursuit, can be attributed to internal or external goals (Deci \& Ryan, 2000; Deci, Vansteenkiste, 2004; Vansteenkiste et al., 2006; Vansteenkiste et al., 2010). Extrenal objectives, which target various material values, seek honor, image and other similar things, cannot directly satisfy the basic psychological needs of a human being. Internal goals for communication and relationships, development and health, ensure direct satisfaction of individual competence, connection and autonomy. According to the position of authors of the Self-determination Theory, a person's selfeducation for healthy lifestyle is associated with internal goals of activity. As self-education is seen as a lifelong process, the goals of a person's individual development oriented activities can be matched with his or her life goals and associated with life outcomes that assure the internal satisfaction.

Essential aspiration of self-education for a healthy lifestyle is the state of fullness, well-being, or eudaimony. In the Theory of Self-determination, eudaimony is not treated as a mental state of man or as a result of a process, but as a path of life, whihe is oriented to the inner values that are important 
10.2478/arhss-2018-0003 Applied Research in Health and Social Sciences, Vol. 15, No. 1, 2018

to human existence and a sense of personal development. The eudaimony-based development, according to authors of the Self-determination Theory (Ryan et al., 2008a), includes:

1) pursuing inner goals and values related to personal growth, interpersonal relations, community and health;

2) autonomous, determinated and voluntary behavior;

3) attentiveness and conscious activity;

4) behavior that satisfies the basic psychological needs of a person for excellence, connection and autonomy.

On the basis of the concept of eudaimony presented above, self-education for a healthy lifestyle should be understood as a consciously chosen path of life, and its aspirations should be equated with the consequences of eudaimony (Ryan et al., 2008a) as it is presented by authors of the Selfdetermination Theory: subjective and psychological well-being, sense of meaning, vitality, better physical health, higher level of inner peace, positive assessment of life, relationship with oneself and with the whole, ability to self-assess and anticipate perspectives.

\section{Conclusions}

Self-education for healthy lifestyle is defined as a process oriented not only to the conscious and purposeful preservation and enhancement of personal health, but also to personal development and improvement. For the conceptualization of self-education for healthy lifestyle construct, it is best to choose the health (self)education theories that are related to the individual level, emphasizing the person's knowledge and experience, attitudes and motivation for change, the ability to realize and manage this change, to develop and maintain socially important relationships for the self-education process.

The Self-Determination Theory reveals the trends of personal development and calls it eudaimony or a path of life based on the satisfaction of general personal psychological needs - autonomy, competence and conenction, as well as the pursuit of inner goals and universally recognized values. Realized and satisfied natural psychological needs encourage person's inner energy, internal motivation associated with person's native inclination for development. In pursuit of personal development and health-oriented goals, a person finds a sense of meaning in his or her activity and experiences a state of well-being. 


\section{sciendo}

10.2478/arhss-2018-0003 Applied Research in Health and Social Sciences, Vol. 15, No. 1, 2018

\section{References}

1. Antonovsky, A. (1987). Unraveling the Mystery of Health: how People manage Stress and Stay Well. San Francisco: Jossey-Bass.

2. Arnold, R. (2010). Selbstbildung oder: wer kann ich werden und wenn ja wie? Baltmannsweiler: Schneider Verlag Hohengehren.

3. Bussolari, C. J., \& Goodell, J. A. (2009). Chaos theory as a model for life transitions counseling: nonlinear dynamics and life's changes. Journal of Counseling \& Development, 87 (1), 98-107.

4. Carlsburg, G.-B., \& von Wehr, H. (2010). Bildung zur Selbstbildung. Konzepte der Professionalisierung und Persőnlichkeitsentwicklung im Lehrerberuf. Augsburg: Brigg Pädagogik Verlag GmbH.

5. Čepanauskienè, R., \& Kalibatienè, D. (2010). Sveikatos įsitikinimų modelio taikymas priešinès liaukos vèžio ankstyvo diagnozavimo stadijoje. Medicinos teorija ir praktika, 16(4), 484-489.

6. Deci, E. L., \& Ryan, R. M. (2000). The "what" and "why" of goal pursuits: human needs and self-determination of behaviour. Psychological Inquiry, 11(4), 227-268.

7. Deci, E. L. \& Vansteenkiste, M. (2004). Self-determination theory and basic need satisfaction: understanding human development in positive psychology. Ricerche di Psicologia, 27(1), 23-40.

8. Giddens, A. (2000). Modernybe ir asmens tapatumas. Vilnius: Pradai.

9. Haggera, M., \& Chatzisarantisb, N. (2008). Self-determination theory and the psychology of exercise. International Review of Sport and Exercise Psychology, 1(1), 79-103.

10. Jankauskas, J. P. (2015). Sveikos gyvensenos pagrindai. Monografija. Vilnius: Vilniaus universiteto leidykla.

11. Janz, N. K., \& Becker, M. H. (1984). The health belief model: a decade later. Health Education \& Behavior, 11(1), $1-47$.

12. Juozapavičienè, D., \& Riklikienè, O. (2013). Požiūrio ị profilaktines storosios žarnos vėžio patikros programas kaita, taikant Sveikatos įsitikinimų modeli. Slaugos mokslas, 9(201), 7-10.

13. Ng, J. Y. Y., Ntoumanis, N., Thøgersen-Ntoumani, C., Deci, E. L., Ryan, R. M., Duda, J. L., \& Williams, G. F. (2012). Self-determination theory applied to health contexts: a meta-analysis. Perspectives on Psychological Science, 7(4) 325-340.

14. Prochaska, J. O., \& DiClemente, C. C. (1983). Stages and processes of self-change of smoking: toward a more integrative model of change. Journal of Consulting and Clinical Psyvchology, 51 (3), 390-395.

15. Prochaska, J. O. (2008). Decision-making in the transtheoretical model of behavior change. Medical Decision Making, 28(6), 845-849.

16. Reinshagen, R. (2008). Antonovsky - theorie und praxis der salutogenese. Pflege und Gesellschaft, 13(2), 142-158.

17. Reis, H. T., Scheldon, K. M, Gable, Sh. L., Roscoe, J., \& Ryan, R. M. (2000). Daily well-being: the role of autonomy, competence, and relatedness. Personality and Social Psychology Bulletin, 26(4), 419-435.

18. Resnicow, K., \& Page, S. E. (2008). Embracing chaos and complexity: a quantum change for public health. American Journal of Public Health, 98(8), 1382-1389.

19. Resnicow, K., \& Vaughan, R. (2006). A chaotic view of behavior change: a quantum leap for health promotion. International Journal of Behavioral Nutrition and Physical Activity, 3(25). Available at: http://www.ncbi.nlm.nih.gov/pmc/articles/PMC1586207 (Accessed on 2018-06-19). 
10.2478/arhss-2018-0003 Applied Research in Health and Social Sciences, Vol. 15, No. 1, 2018

20. Ryan, R. M. (1995). Psychological needs and the facilitation of integrative processes. Journal of Personality, 63(3), 397-427.

21. Ryan, R. M. (2009). Self-Determination Theory and Wellbeing. WeD Research Review, 1. Available at: http://www.bath.ac.uk/soc-pol/welldev/wed-new/network/research-review/Review_1_Ryan.pdf (Accessed on 201802-10).

22. Ryan, R. M., \& Deci, E. L. (2000 a). Self-determination theory and the facilitation of intrinsic motivation, social development, and well-being. American Psychologist, 55(1), 68-78.

23. Ryan, R. M., \& Deci, E. L. (2000 b). The darker and brighter sides of human existence. Psychological Inquiry, 11(4), 319-338.

24. Ryan, R. M., \& Deci, E. L. (2006). Self-regulation and the problem of human autonomy: does psychology need choice, self-determination, and will? Journal of Personality, 74(6), 1557-1585.

25. Ryan, R. M., Huta V. \& Deci, E. L. (2008 a). Living well: a self-determination theory perspective on eudaimonia. Journal of Happiness Studies, 9(1), 139-170.

26. Ryan, R. M., Patrick, H., Deci, E. L., \& Williams, G. C. (2008 b). Facilitating health behaviour change and its maintenance: interventions based on self-determination theory. European Health Psychologist, 10, 2-5.

27. Salci, M. A., Maceno, P., Rozza, S. G., Silva, D. M. G. V., Boehs, A. E., \& Heidemann, I. T. S. B. (2013). Health Education and its Theoretical Perspectives: a Few Reflections. Text Context Nursing, 22(1), 224-230.

28. Segar, M. (2015). The right why: the surprising start to cultivating sustainable behavior change. Generations, 39(1), 15-19.

29. Sheldon, K., \& Niemiec, C. (2006). It's not just the amount that counts: balanced need satisfaction also affects wellbeing. Journal of Personality and Social Psychology, 91(2), 331-341.

30. Teixeira, P. J., Patrick, H., \& Mata, J. (2011). Why we eat what we eat: the role of autonomous motivation in eating behaviour regulation. Nutrition Bulletin, 36(1), 102-107.

31. Vansteenkiste, M., Lens, W., \& Deci, E. L. (2006). Intrinsic versus extrinsic goal contents in self-determination theory: another look at the quality of academic motivation. Educational Psychologist, 41(1), 19-31.

32. Vansteenkiste, M., Niemiec, C., \& Soenens, B. (2010). The development of the five mini-theories of selfdetermination theory: an historical overview, emerging trends, and future directions. In Urdan, T., Karabenick, S. (Eds.). Advances in Motivation and Achievement, (Vol. 16). Bingley, UK: Emerald Publishing.

33. Vansteenkiste, M., \& Ryan, R. M. (2013). On psychological growth and vulnerability: basic psychological need satisfaction and need frustration as a unifying principle. Journal of Psychoterapy Integration, 23(3), 263-280.

34. Wiggins, N. (2011). Popular Education for Health Promotion and Community Empowerment: a Review of the Literature. Health Promotion International, 27 (3), 356-371.

35. Wilson, Ph. M., Mack, D. E., \& Grattan, K. P. (2008). Understanding motivation for exercise: a self-determination theory perspective. Canadian Psychology, 49(3), 250-256. 